\title{
METAP2 wt Allele
}

National Cancer Institute

\section{Source}

National Cancer Institute. METAP2 wt Allele. NCI Thesaurus. Code C143020.

Human MET AP2 wild-type allele is located in the vicinity of $12 q 22$ and is approximately $42 \mathrm{~kb}$ in length. This allele, which encodes methionine aminopeptidase 2 protein, is involved in nascent protein processing and the regulation of angiogenesis. 